\title{
SYMBOLIC AND FUNCTIONAL BRAND EFFECTS FOR MARKET SEGMENTATION
}

\author{
Kevin Kuan-Shun Chiu (corresponding author) \\ Lunghwa University of Science and Technology, Taiwan \\ E-mail: kevinchiu@msn.com \\ Ru-Jen Lin \\ Lunghwa University of Science and Technology, Taiwan \\ E-mail: rjlin@mail.lhu.edu.tw \\ Maxwell K. Hsu \\ University of Wisconsin-Whitewater, USA \\ Email:hsum@uww.edu \\ Shih-Chih Chen \\ Tatung University, Taiwan \\ E-mail:scchendr@gmail.com
}

\begin{abstract}
This study investigates the interrelationships among brand personality, brand preference, customer perceived value, and golfers' performance in the context of Taiwan's golf clubs market. The theoretical and statistical relationships among these constructs are developed and verified. Using survey data from 345 out of 1,000 randomly selected golfers, this study employs ANOVA, Factor Analysis, and Discriminant Analysis to examine the research hypotheses. The findings reveal that (1) notable brand personality factors including Reliability, Fashion, Masculine, Excitement, Wholesome, Leadership, Sentiment, Feminine, and Uniqueness could explain brand preference to a large extent, (2) golfers' customer perceived value regarding various golf brands are considerably dissimilar, and (3) golfers' deviation in performance significantly relates to brands. In addition to conventional bases for market segmentation (i.e., demographics, psychographics, lifestyles, etc.), this paper clearly provides practical guidelines of implementing brand personality for market segmentation and promotion strategies. Brand personality proves to be a useful segmenting variable. The findings and the statistical results offer supportive evidence for implementing appropriate branding management on both functional (i.e., customer perceived value and performance) and emotional attributes (i.e., brand personality) in order to enhance competitiveness.
\end{abstract}

Keywords: Brand Personality, Brand Preference, Market Segmentation, Customer Perceived Value, Golfer's performance.

\section{INTRODUCTION}

The golf industry is competitive in almost every part in the world. Producers of golf equipments (such as Callaway, Taylor Made, \& Titleist) usually target the same market segment and cannibalize market share as a result. With an industry facing fierce competition, companies are experiencing pressure to maintain their profits. Branding is an important intangible asset of a company that could transmit promise, acceptance, trust, and hope to patrons. This circumstance is especially true in sports. Indeed, a recent internet survey in 2007 (Beijing Full Honor Warrant Information Consulting Co. Ltd., 2008) reports that golfers have an affirmative worship of brand; namely, they enclose significant brand preferences. The golf equipment consumers identify themselves with the product which implicitly carries a status symbol (Beijing Full Honor Warrant Information Consulting Co. Ltd., 2008). However, to the best knowledge of the authors, only a paucity of empirical research has focused on the 'symbolic use of brands' (Aaker, 1997: 347) in the golf club industry. To fill this gap, the current study attempts to study to what extent marketers may utilize this concept to differentiate golf club brands.

Past research suggests that brand personality boosts consumer preference (Zhang, 2007) and has a positive relationship with levels of consumer trust and loyalty (Wysong, Munch, \& Kleiser, 2004). Moreover, customer perceived value provides marketers a clue on how to better satisfy the needs of their targeted customers (Lin, 2002). Additionally, perceived performance or quality serve as an important antecedent of value and either directly or indirectly drives repurchase intention (Olorunniwo \& Hsu, 2006). On the other hand, every brand in the golf market claims that its trademark offers the greatest extent for best possible distance, control, accuracy, reliability, playability, and self-confidence (Ellis, 2004). Thus, the present study attempts to investigate the 
interrelationships among brand personality, brand preference, customer perceived value, and golfers' performance with respect to different golf equipment brands.

The conceptual model of this study is depicted in Figure 1.

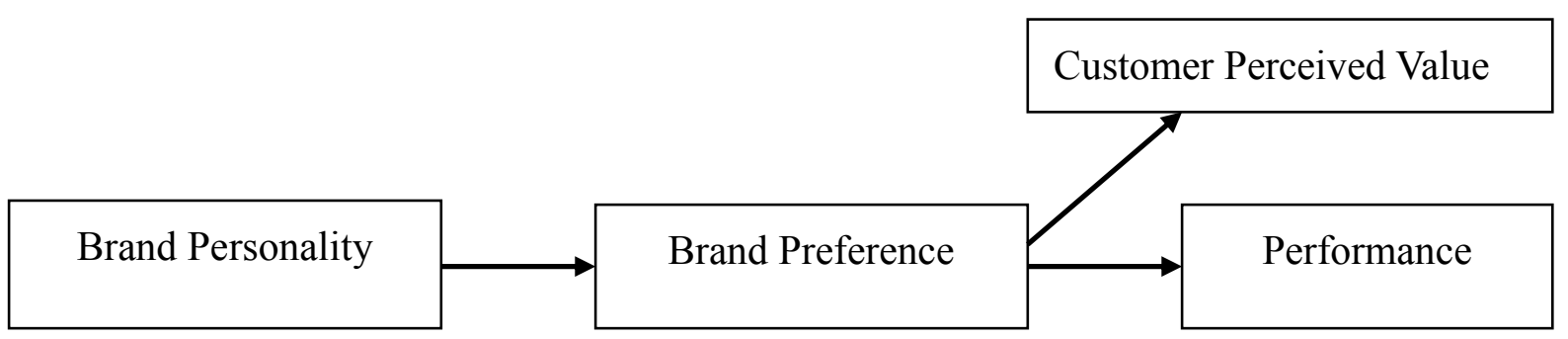

Figure 1: Conceptual Model

The purposes of the present study are as follows: (1) to investigate the relationship between brand personality and brand preference of golf clubs, (2) to study golfers' perceived value toward various brands, and (3) to explore the possible linkage between golfer's performance and their chosen golf club brands.

\section{LITERATURE REVIEW}

\subsection{Brand Preference}

Brand preference refers to the consumers' hierarchical prioritisation of the brand as a result of their patronage and cognitive comprehension of the brand (Singh, Ehrenberg, \& Goodhardt, 2008). Customer merchandise carries much more meaning than their utilitarian, functional, and commercial significance (Terpstra \& Sarathy, 1997). Individuals are more likely to buy brands whose personalities intimately match their own self images (Schiffman \& Kanuk, 2000) and self expression (Jamal \& Goode, 2001). Moreover, consumers express themselves by selecting brands whose personalities are consistent with their own personalities (Aaker, 1999).

Self image or self expression affects consumers' product preferences and their purchase intentions (Mehta, 1999). Ericksen (1996) finds a significant relationship between self image and intention to buy an American brand automobile (Ford Escort). In other words, 'individuals prefer brands that have images compatible with their perceptions of self' (Jamal \& Goode 2001: 483). This self image consistency strengthens positive attitude toward products and brands (Sirgy, et al. 1997). Specifically, Graeff (1996: 5) notes that 'the more similar a consumer's self-image is to the brand's image, the more favorable their evaluations of that brand should be'.

In general, consumers have a brand preference toward an established brand during the firm's long presence in the market (Dinlersoz \& Pereira, 2007) and they tend to show little brand preference toward a particular brand when they are exposed to a new or unfamiliar product category. Research indicates that the greater their shopping experiences and/or information collection, the higher the probability of focusing on a specific brand (Devaraj, Fan, \& Kohli, 2006).

\subsection{Brand Personality}

Brand personality refers to 'the set of human characteristics associate with a brand' (Aaker, 1997: 347). Contrary to performance-oriented product attributes, brand personality appears to be representative/self-expressive oriented (Keller, 1993; Fennis \& Pruyn, 2007). Moreover, it has been suggested that brand personality facilitates a consumer to articulate his/her self (Belk, 1988), an ideal self (Malhotra, 1988), or exact aspects of the self (Kleine, et al. 1993). Additionally, this concept is an essential determinant of consumer preference and usage (Biel, 1993).

Any direct/indirect contact that the consumer has with a brand can influence brand personality (Plummer, 1985). Brand's user imagery is shaped by direct influences or 'the set of human characteristics associated with the typical user of a brand' (Aaker, 1997: 348), the firm's workers and/or boss, and the brand's endorsers. On the other hand, the indirect influences contain product-related features, product category relationships, brand name, mark or emblem, and other marketing mix elements (Batra, Lehmann, \& Singh, 1993).

Customers tend to select and use brands with various salient personality dimensions to highlight certain aspects of their own personality in various situational contexts (Aaker, 1999; Helgeson \& Supphellen, 2004). According to Sung and Tinkham (2005), brand personality is a hypothetical construct developed by consumers and it differs from human personality. Individuals possess the human personality traits composed of implicit 
(perceived) and actual (objective) components, independent of the perceivers' characterization. In contrast, no objective personality traits exist in brand. Aaker, Fournier, and Brasel (2004) note that as the connection between brand and the customer interacts, the personality traits have direct influence on this interaction.

\subsection{Customer Perceived Value}

Customer perceived value is a critical notion in the marketing literature (Hansen, Samuelsen, \& Silseth, 2008). Specifically, customer perceived value in commerce marketplace is defined as 'the trade-off between the multiple benefits and sacrifices of a supplier's offering, as perceived by key decision-makers in the customer's organization, and taking into consideration the available alternative suppliers' offerings in a specific use situation' (Eggert \& Ulaga, 2002: 110).

Three notable elements exist in this definition: '(1) the multiple components of value, (2) the subjectivity of value perceptions, and (3) the importance of competition' (Eggert \& Ulaga, 2002: 109). Ulaga and Eggert (2006) advance the trade-off notion and focus on the multidimensional nature of benefits and sacrifices rather than tangibles. First of all, the multiple benefits refer to a mixture of product/service attributes and/or technological support available related to a specific use condition (Monroe, 1990) and occasionally illustrated in monetary forms (Anderson, Jain, \& Chintagunta, 1993). Second, customers' perceived value is subjective, not objective, in nature (Kortge \& Okonkwo, 1993). In other words, different customers may have a variety of perceived values for the same product/service. Third, customers' perceived value is closely tied with competition in the marketplace. Competitors generate sustainable competitive advantage by means of bringing a better trade-off between utilities and sacrifice in a merchandise/service.

It is noteworthy that customer perceived value is not only a take factor (i.e., the benefits that a purchaser obtains from the vendor's contribution) but also a give factor (i.e., the buyer's costs of receiving the offering) (Dodds, 1991). Much of the precedent studies identify product quality as the primary take factor and price as the give factor (Grewal, Monroe, \& Krishnan, 1998). In addition, 'service is also a logical driver of perceived value' (Parasuraman \& Grewal, 2000: 169). Sellers provide outstanding sales services in order to increase the benefits perceived by the buyer and to 'decrease the buyer's non-monetary costs, such as time, effort, and mental stress' (Parasuraman \& Grewal, 2000: 169). Marketing practitioners and academicians concern how customers perceive and evaluate the value of products and services (Boshoff \& Gray, 2004; Ulaga \& Eggert, 2006; Naidoo \& Leonard, 2007).

\subsection{Performance}

Performance orientation refers to 'the desire to use one's work to achieve valued external ends' (Sujan, et al. 1994: 39; Phusavat, et al. 2009). In other words, this direction leads to accomplish an optimistic assessment of people's current abilities (Ho, 2009).

The advanced technology enables the development of high-tech golf equipments which has changed the nature of this sport. Successful examples include 'the high-modulus graphite shafts, titanium-headed drivers, and multi-core urethane-cover balls' (Murphy, 2006: 30). Today, armed with these high-tech golf equipments, a normal golfers can score better with more fun because they can more confidently hit the balls farther and straighter. It is observed that 'changes have benefited the average golfers even more than the tour professionals' (Murphy, 2006: 35). Even a novice golf player knows that he/she should seek for innovative equipments in order to make his/her game better.

Regarding golf equipments in Taiwan, there are more than a dozen of known brands in the market. Manufacturers create golf clubs with new technology for best possible distance, control, accuracy, reliability, playability, and self-confidence (Ellis, 2004). Notable characteristics of new technology include larger club head size with superior sweet spot produces higher inertia for increased forgiveness (i.e., greater stability on off-center impacts), various centers of gravity create different launch angles, and an assortment of lofts and shafts generate low spin with maximum ball velocity (Karlsen \& Nillson, 2007). Almost all brands in the market claim that this trademark offers the greatest extent for these characteristics. In other words, every specific brand tries to convince golfers that the clubs of this brand name help consumers increase their enjoyment of this exercise (i.e., better score, longer distance, and even less practice). However, an empirical investigation on the relationships between discrepancy in performance and a variety of brands of golf equipments has remained scarce.

Based on the above discussion, the following hypotheses are formed:

H1. A significant relationship exists between brand personality and brand preference.

H2. A significant relationship exists between brand preference and customer perceived value.

H3. Brand preference is significantly associated with golfers' performance.

\section{METHODOLOGY}

A pilot study that involved a small sample of 30 respondents was administered to assess both individual 
questions and sequence (Churchill, 1995). Only minor changes on the wording were carried out by the authors. The research design included a cross-sectional field study. A questionnaire with a stamped return envelope was sent to 1,000 randomly selected golfers who frequently visit golf driving ranges in the Taipei Metropolitan area, Taiwan in Mar. 2008. Statistical methods (e.g., ANOVA, Factor Analysis, \& Discriminant Analysis) are employed respectively to examine the research hypotheses.

\subsection{Measurements and Scales}

(1). Brand Personality

A number of studies have applied the Brand Personality Scale across different product categories (Aaker, 1997; Sung \& Tinkham, 2005; Chiu, et al., 2010b). According to Aaker (1997: 348), this scale 'enables researchers to understand the symbolic use of brands in general vs. the symbolic use of brands within a particular category and provides theoretical insights into when and why consumers buy brands for self-expressive purposes'. This study uses a 7-point Likert-type scale ( $1=$ strongly disagree to $7=$ strongly agree) and asks respondents 'to think of each brand as if it were a person' (Aaker, 1997: 350) but to evaluate the degree to which the set of human characteristics describes the specific brand.

(2). Brand Preferences

Respondents are asked to mark their brand preferences among the following list of brands: Ben Hogan, Bridge Stone, Callaway, Cleveland, Cobra, Daiwa, Dunlop, Honma, Kasco, MacGregor, Maruman, Maxfli, Mizuno, Nike, Orlimar, Ping, Precept, PRGR, Ram, Sonartec, Taylor Made, Titleist, Wilson, Yamaha, Yonex, and others (please specify) (http://www.golfdiscount.com/category/golf_clubs).

(3). Customer Perceived Value

Parasuraman and Grewal (2000: 169) define that customer perceived value composes 'service quality, product quality, and price': detailed literature review of this concept can be retrieved in a previous study (Chiu, et al., 2010a). With a 7-point Likert-type scales ( $1=$ strongly disagree to $7=$ strongly agree $)$, this study used a combination of measurements (Dodds, Monroe, \& Grewal, 1991; Petrick, 2002) to scrutinize this construct (Chiu, et al., 2010a).

(4). Performance

Based on the PGA Tour statistics (http://www.pgatour.com/stats), scoring average, driving distance, driving accuracy, greens hit in regulation, putts per round, sand saves, and birdies per round are certified measurements for golfers' performance. Since the sample of this study does not focus on professional golfers, the authors decided to employ only driving distance (yards) as measurement for this construct.

(5). Demographic characteristics

Personal information such as gender, age, education, marital status, income, height, and weight are collected too.

\section{RESULTS}

Three hundred and sixty one responses out of the one thousand randomly mailed questionnaires returned to the authors in Apr. 2008, but only 345 completed responses were used for statistical analyses in the present study. $93 \%$ of these golfers are males and $74.2 \%$ of the respondents are married. More than $90 \%$ of these respondents are younger than 55 years and the largest group (44.3\%) falls in the 36-45 age category. Regarding income level, $73.6 \%$ of these samples' earnings are lower than $\$ 1,200,000$ NTD; $10 \%$ of them earn more than $\$ 2,100,000$ NTD. In comparison, the average GDP per capital of 2007 in Taiwan is approximately \$650,000 NTD (approximately $\$ 19,700$ USD). Thus, it appears that these respondents represent a relatively high social-economic class in Taiwan. As mentioned above, the principal construct measures were all based on existing instruments with established content validity (Kerlinger, 1986) and "have been previously checked for validity and reliability" (Song, Benedetto, and Parry, 2009: 317). Notably, the coefficient alphas related to all studied factors exceeded .7, the minimum requirement of construct reliability (Nunnally, 1978).

To investigate H1 - 'A significant relationship is between brand personality and brand preference,' factor analysis (principal component method with varimax rotation) was employed to analyze the data. Among these 42 independent variables, the Pearson Correlation Coefficients matrix yielded an almost zero determinant $\left(2.06^{*} 10^{-19}\right)$ indicating that 'there are linear dependencies among the response variables and there are likely to be underlying common factors' (Johnson, 1998: 162). Therefore, these independent variables were trimmed to a smaller set of factors. The consequential factor loadings are also reported in Table 1.

In this study, 'a principal components factor analysis with varimax rotation' was also utilized to examine the validity of construct (Hsu, Chou, \& Hsu, 2008: 255). Convergent validity was evaluated based on the standard provided by Fornell and Larcker (1981) that all indicator factor loadings should be statistically significant at the 0.05 level and exceed 0.5. Based on the results in Table 1, all indicator variables (except intelligent and western are slightly lower than 0.5 ) provide good measures to their respective construct which provide supportive evidence to convergent validity. 
Table 1: Factor analysis for brand personality

\begin{tabular}{|c|c|c|c|c|c|c|c|c|c|}
\hline & \multicolumn{9}{|c|}{ Component } \\
\hline & Reliability & Fashion & Masculine & Excitemen & Wholeso & Leadershi & Sentiment & Feminine & Uniauenes \\
\hline down to & .159 & -.133 & .212 & .055 & .647 & -.053 & .258 & -.041 & .231 \\
\hline family oriented & .080 & -.151 & .018 & .288 & .399 & -.038 & .592 & .171 & .060 \\
\hline small town & .285 & .151 & .228 & .120 & -.075 & .014 & .686 & .241 & -.081 \\
\hline honest & .267 & .001 & .532 & -.039 & .389 & .100 & .493 & -.102 & -.136 \\
\hline sincere & .376 & .234 & .548 & -.062 & .297 & .039 & .462 & -.026 & -.138 \\
\hline real & .550 & -.059 & .215 & .101 & .594 & -.004 & .191 & .072 & -.149 \\
\hline wholesome & .431 & .026 & .233 & .174 & .710 & .042 & .033 & .097 & -.031 \\
\hline original & .188 & .461 & -.112 & .394 & .081 & -.012 & .046 & .103 & .573 \\
\hline cheerful & .498 & .181 & .180 & .528 & .094 & .090 & .043 & .023 & .313 \\
\hline sentimental & -.127 & .056 & -.099 & -.147 & .090 & .231 & .742 & .111 & .154 \\
\hline friendly & .381 & .159 & .092 & -.053 & .612 & .005 & -.055 & .318 & .225 \\
\hline daring & .079 & .381 & .491 & .281 & .291 & .071 & .071 & -.020 & .208 \\
\hline trendv & .148 & .603 & -.067 & .411 & .127 & .022 & -.220 & .133 & .321 \\
\hline exciting & .238 & .263 & .113 & .791 & .029 & .139 & .042 & 109 & -.020 \\
\hline spirited & .270 & .336 & .158 & .560 & .369 & .171 & .041 & .076 & .113 \\
\hline cool & .555 & .180 & .049 & .287 & .198 & .336 & .084 & -.083 & .124 \\
\hline voung & -.079 & .841 & .107 & .100 & .042 & .115 & .007 & -.010 & .154 \\
\hline imaginative & .101 & .737 & .316 & .204 & .034 & .171 & .084 & .030 & .084 \\
\hline unique & .722 & .163 & .139 & .274 & .107 & .207 & .075 & -.153 & .115 \\
\hline up to date & .072 & .790 & -.011 & .197 & -.112 & .069 & .087 & .248 & -.161 \\
\hline independent & .462 & .239 & .542 & .216 & -.068 & .354 & .159 & -.093 & .031 \\
\hline contemporar & .267 & .509 & .449 & .521 & -.193 & .109 & .022 & .065 & .054 \\
\hline reliable & .803 & .000 & .280 & .172 & .054 & .105 & -.024 & -.001 & .061 \\
\hline hardworking & .487 & .027 & .645 & .124 & .145 & .182 & .141 & .080 & .113 \\
\hline secure & .688 & .038 & .246 & .146 & .151 & -.024 & -.006 & .263 & .205 \\
\hline intelligent & .463 & .426 & .296 & -.137 & .033 & .219 & .133 & .187 & .217 \\
\hline technical & .767 & .096 & .132 & .125 & .177 & .070 & .082 & -.164 & .043 \\
\hline corporate & .272 & .264 & .444 & .009 & .147 & .230 & .316 & -.017 & .530 \\
\hline successful & .580 & .145 & .138 & .200 & .197 & .399 & -.106 & .022 & .368 \\
\hline leader & .302 & .237 & .271 & .061 & .139 & .770 & .065 & .006 & .098 \\
\hline confident & .589 & .043 & .184 & .488 & .088 & .310 & -.044 & .002 & .194 \\
\hline upper class & .255 & .090 & .094 & .175 & -.078 & .769 & .107 & .173 & -.116 \\
\hline glamorous & .308 & .039 & .361 & .258 & .039 & .662 & .111 & .120 & .234 \\
\hline good looking & .023 & .429 & .115 & .480 & -.138 & .515 & .126 & .151 & .027 \\
\hline charming & .368 & .215 & .106 & .658 & .166 & .225 & -.019 & .074 & -.002 \\
\hline feminine & -.049 & .180 & -.148 & .104 & .175 & .039 & .115 & .860 & .048 \\
\hline smooth & -.103 & .102 & .114 & .110 & -.031 & .181 & .215 & .842 & -.003 \\
\hline outdoorsv & .282 & .049 & .717 & .135 & .178 & .178 & -.220 & .225 & .005 \\
\hline masculine & .274 & .153 & .707 & .164 & .209 & .224 & .068 & -.302 & -.007 \\
\hline western & .322 & .395 & -.044 & .083 & .486 & .374 & .006 & -.244 & -.169 \\
\hline tough & .719 & -.016 & .134 & .184 & .298 & .251 & .115 & -.067 & -.119 \\
\hline rugged & .755 & -.011 & .177 & .043 & .329 & .187 & .113 & -.030 & -.132 \\
\hline Eigenvalues & 15.58 & 4.28 & 2.72 & 2.27 & 1.84 & 1.38 & 1.26 & 1.13 & 1.09 \\
\hline Cumulative & & & & & & & & & \\
\hline$\%$ of & 17.18 & 27.04 & 36.58 & 45.17 & 52.8 & 60.3 & 66 & 71.35 & 75.10 \\
\hline Variance & & & & & & & & & \\
\hline
\end{tabular}

Extraction Method: Principal Component Analysis.

Rotation Method: Varimax with Kaiser Normalization 
After evaluating the make-up of each factor, representative names were picked to reflect the underlying meaning of these factors. The names designated to each factor were as follows: Factor 1- Reliability, Factor 2- Fashion, Factor 3- Masculine, Factor 4- Excitement, Factor 5- Wholesome, Factor 6- Leadership, Factor 7- Sentiment, Factor 8- Feminine, and Factor 9- Uniqueness. Together, these factors explained $75.10 \%$ of the variance of the 42 original independent variables. Subsequently, stepwise discriminant analysis (Hemmasi \& Graf, 1993) was used to determine whether these factors were significant predictors for brand preference. Results indicated Reliability, Fashion, Masculine, Excitement, Wholesome, Leadership, Sentiment, Feminine, and Uniqueness are significant brand personality factors $(\chi 2=33.412$, d.f. $=16, p<0.007)$ for explaining brand preference (see Table 2 for the prediction classification).

Table 2: Classification Results

\begin{tabular}{|c|c|c|c|c|c|c|c|c|c|c|c|c|c|c|c|c|}
\hline $\begin{array}{l}\text { Cross-validated } \\
\%\end{array}$ & (1) & (2) & (3) & (4) & (5) & (6) & (7) & (8) & (9) & (10) & (11) & (12) & (13) & (14) & (15) & (16) \\
\hline Brand \& N & & & & & & & & & & & & & & & & \\
\hline $\begin{array}{l}\text { (1) Bridge } \\
\text { Stone-7 }\end{array}$ & $\begin{array}{r}100 . \\
0\end{array}$ & .0 & .0 & .0 & .0 & .0 & .0 & .0 & .0 & .0 & .0 & .0 & .0 & .0 & .0 & .0 \\
\hline (2) Callaway-39 & .0 & 25.6 & 7.7 & .0 & .0 & .0 & .0 & .0 & .0 & .0 & .0 & 7.7 & .0 & 25.6 & 25.6 & 7.7 \\
\hline (3) Cleveland-10 & .0 & .0 & 50.0 & .0 & .0 & .0 & .0 & .0 & .0 & .0 & .0 & .0 & .0 & .0 & 50.0 & .0 \\
\hline (4) Cobra-9 & .0 & .0 & .0 & .0 & .0 & .0 & .0 & .0 & 30.0 & .0 & 30.0 & .0 & .0 & .0 & 40.0 & .0 \\
\hline (5) Daiwa-3 & .0 & .0 & .0 & .0 & $\begin{array}{r}100 . \\
0\end{array}$ & .0 & .0 & .0 & .0 & .0 & .0 & .0 & .0 & .0 & .0 & .0 \\
\hline (6) Dunlop-13 & .0 & .0 & .0 & .0 & .0 & 25.0 & .0 & .0 & .0 & .0 & .0 & 25.0 & .0 & 50.0 & .0 & .0 \\
\hline (7) Honma-19 & .0 & 15.8 & .0 & .0 & .0 & .0 & 36.8 & .0 & .0 & .0 & .0 & .0 & .0 & 15.8 & 31.6 & .0 \\
\hline (8) Kasco-3 & .0 & .0 & .0 & .0 & .0 & .0 & .0 & $\begin{array}{r}100 . \\
0\end{array}$ & .0 & .0 & .0 & .0 & .0 & .0 & .0 & .0 \\
\hline (9) Maruman-7 & .0 & .0 & .0 & .0 & .0 & .0 & .0 & .0 & 42.9 & .0 & 57.1 & .0 & .0 & .0 & .0 & .0 \\
\hline (10) Maxfli-3 & .0 & 100 & .0 & .0 & .0 & .0 & .0 & .0 & .0 & .0 & .0 & .0 & .0 & .0 & .0 & .0 \\
\hline (11) Mizuno-36 & .0 & 8.3 & .0 & .0 & .0 & .0 & .0 & .0 & .0 & 8.3 & 50.0 & .0 & .0 & 25.0 & 8.3 & .0 \\
\hline (12) Nike-29 & 10.0 & 10.0 & .0 & .0 & .0 & 10.0 & .0 & .0 & .0 & .0 & .0 & 10.0 & 10.0 & 26.7 & 23.3 & .0 \\
\hline $\begin{array}{l}\text { (13) Ping-24 } \\
\text { (14)Taylor }\end{array}$ & .0 & .0 & .0 & .0 & .0 & .0 & .0 & .0 & .0 & .0 & 12.5 & .0 & 62.5 & 25.0 & .0 & .0 \\
\hline $\begin{array}{l}\text { Made } \\
-53\end{array}$ & 5.7 & .0 & .0 & .0 & .0 & .0 & .0 & .0 & .0 & .0 & 5.7 & 5.7 & 7.5 & 50.9 & 24.5 & .0 \\
\hline (15) Titleist-72 & .0 & 4.2 & .0 & .0 & .0 & 5.6 & 8.3 & .0 & .0 & .0 & 12.5 & .0 & .0 & 9.7 & 55.6 & 4.2 \\
\hline (16) Wilson- 7 & .0 & .0 & .0 & .0 & .0 & .0 & .0 & .0 & .0 & .0 & .0 & .0 & .0 & 57.1 & .0 & 42.9 \\
\hline
\end{tabular}

\section{A. $\mathbf{5 3 . 5 \%}$ of original grouped cases correctly classified.}

\section{B. $43.8 \%$ of cross-validated grouped cases correctly classified.}

Various levels of success were observed when the discriminant analysis was used to predict the ownership of 16 golf equipment brands. Table 2 shows that the stepwise discriminant analysis correctly predicts the ownership for $100 \%$ of Bridgestone, $25.6 \%$ of Callaway, $50 \%$ of Cleveland, $100 \%$ of Daiwa, $25 \%$ of Dunlop, $36.8 \%$ of Honma, $100 \%$ of Kasco, $42.9 \%$ of Maruman, $50 \%$ of Mizuno, $10 \%$ of Nike, $62.5 \%$ of Ping, $50.9 \%$ of Taylor Made, $55.6 \%$ of Titleist, $42.9 \%$ of Wilson, and accurately classifies $53.5 \%$ of original grouped cases as well as $43.8 \%$ of cross-validated categorised respondents. Given that 16 golf brands were included in the present study, a naive prediction $(100 / 16 * 100 \%)$ of golf equipment brand ownership would produce an accuracy rate of 0.0625 . Comparing the $6.25 \%$ prediction benchmark, the above model considerably increases the prediction accuracy. 
Moreover, the effects of brand personality factors upon brands were examined by using ANOVA (Ong and Lai, 2006). The greatest mean scores, standard deviations, and significance p values are shown in Table 3.

Table 3: Descriptive statistics and ANOVA testing

\begin{tabular}{|c|c|c|c|c|}
\hline Brand personality factor & Greatest mean & S.D. & Brand & p value \\
\hline Reliability & 5.94 & 0.77 & Ping & 0.000 \\
\hline Fashion & 5.65 & 0.48 & Nike & 0.000 \\
\hline Masculine & 6.17 & 0.71 & Cleveland & 0.000 \\
\hline Excitement & 6.12 & 0.79 & Callaway & 0.000 \\
\hline Wholesome & 6.14 & 0.7 & Ping & 0.000 \\
\hline Leadership & 5.8 & 1.03 & Titleist & 0.000 \\
\hline Sentimental & 4.31 & 0.5 & Ping & 0.001 \\
\hline Feminine & 6.1 & 1.12 & Mizuno & 0.000 \\
\hline Uniqueness & 5.7 & 0.91 & Taylor Made & 0.000 \\
\hline
\end{tabular}

Findings indicate that variance in perception of brand personality is significantly related to different brands. Therefore, these results provided support to Hypothesis 1 .

To examine H2- 'Brand preferences significantly associate with variation in customers' perceived value,' ANOVA (Chiu, et al., 2010a) was employed to determine whether significant disparity exists between group means. Results indicated that significant differences $(\mathrm{p}<0.000)$ present between brand preference and customer perceived value. Table 4 demonstrates the ad-hoc relationship and these results support Hypothesis 2.

Table 4: Brand Preference vs. Customer Perceived Value

\begin{tabular}{|c|c|c|}
\hline Brands & Perceived Product Quality & Product Perceived Value \\
\hline Cleveland & $\begin{array}{c}\text { Greatest mean } \sim \text { reliability, workmanship, } \\
\text { dependability, \& durability. }\end{array}$ & Greatest mean acceptable price. \\
\hline Honma & Lowest mean reliability \& \\
dependability. & Lowest mean economical price \\
\hline Kasco & Greatest mean $\sim$ reliability, quality, & Greatest mean value for money \& a good buy. \\
\hline Nike & Lowest mean $\sim$ durability. & Lowest mean a good buy and bargain. \\
\hline Ping & Lowest mean $\sim$ workmanship, quality, & Greatest mean economical price, \\
\hline Wilson & & Lowest mean value for money. \\
\hline
\end{tabular}

To explore H3- 'Brand preference significantly associates with respondent's performance,' ANOVA (Chiu, et al, 2010a) was again utilized to examine whether significance difference exists between group means. Results reveal that significant inequality $(\mathrm{p}<0.000)$ presents between brand preference and performance. Table 5 demonstrates the ad-hoc relationship and these results support Hypothesis 3. 
Table 5: Driver brands vs. performance (driving distance- yards)

\begin{tabular}{|c|c|c|c|c|c|}
\hline Brands & $\mathrm{N}$ & Mean & Std. Deviation & Minimum & Maximum \\
\hline No & 5 & 148.75 & 99.19 & .00 & 200.00 \\
\hline Callaway & 43 & 232.90 & 30.90 & 175.00 & 290.00 \\
\hline Cleveland & 18 & 262.50 & 17.25 & 235.00 & 290.00 \\
\hline Cobra & 15 & 246.00 & 11.83 & 220.00 & 260.00 \\
\hline Daiwa & 3 & 190.00 & 10.00 & 180.00 & 200.00 \\
\hline Dunlop & 7 & 211.42 & 13.45 & 190.00 & 230.00 \\
\hline Honma & 9 & 256.66 & 51.47 & 180.00 & 310.00 \\
\hline Kasco & 9 & 260.00 & 19.36 & 230.00 & 290.00 \\
\hline MacGregor & 4 & 260.00 & 8.16 & 250.00 & 270.00 \\
\hline Maruman & 14 & 234.28 & 32.74 & 190.00 & 280.00 \\
\hline Maxfli & 4 & 160.00 & 8.16 & 150.00 & 170.00 \\
\hline Mizuno & 13 & 244.61 & 28.17 & 190.00 & 280.00 \\
\hline Nike & 10 & 262.00 & 15.49 & 240.00 & 290.00 \\
\hline Orlimar & 3 & 260.00 & 10.00 & 250.00 & 270.00 \\
\hline Ping & 10 & 230.00 & 28.28 & 190.00 & 270.00 \\
\hline PRGR & 3 & 240.00 & 10.00 & 230.00 & 250.00 \\
\hline Taylor Made & 103 & 254.12 & 21.67 & 200.00 & 300.00 \\
\hline Titleist & 39 & 261.15 & 14.79 & 230.00 & 295.00 \\
\hline Wilson & 7 & 230.00 & 8.16 & 220.00 & 240.00 \\
\hline Yamaha & 3 & 200.00 & 10.00 & 190.00 & 210.00 \\
\hline others & 23 & 217.39 & 90.91 & .00 & 290.00 \\
\hline Total & 345 & 243.76 & 39.09 & .00 & 310.00 \\
\hline
\end{tabular}

\section{DISCUSSION, IMPLICATION, AND CONCLUSION}

Branding has been one of the most imperative commercial topics over the last decades (Boshoff, Schlechter, \& Ward, 2011). What is 'brand value' (Raggio \& Leone, 2009: 248)? 'A brand is made up of three things: what a company sells, what a company does, and what a company is' (Davis, 2000: 4).

Regarding what a company sells, the scope of this study focuses only on the product line of golf clubs. For example, Titleist sells not only golf clubs but also golf balls and gear (i.e., clothes, caps, \& footwear, etc.). These merchandises are not in the scope of this study.

Concerning the subject of what a company does, the findings of this study are consistent with the works of Hellier, et al. (2003). Consumers do have significant and diverse brand recognition with perceived value among a variety of brands. 'The influence of brand names on quality judgments' does exist ( $\mathrm{Na}$, et al. 2008: 195). In order to retain customers, managers should focus on improving customers' perceived equality of services and goods (Klaus and Maklan, 2007). Consequently, firms shall make the most of highly appraised customer perceived value variable(s) as part of the marketing elements and develop their competitive advantage/s for increasing market share, sales, profit, and brand image (Phusavat and Kanchana, 2008a).

On the subject of what a company is, customers often have various perceptions in brand personality among different brands. 'The strongest brands find the appropriate balance between functional and emotional attributes' (Bergstrom, 2000: 12; Priilaid \& Rensburg, 2010). Functional attributes refer to tangible characteristics such as 
performance, quality, and price while emotional attributes refer to intangible features such as 'how the brand makes you feel' (Bergstrom, 2000: 13). The findings of the current study offer additional support to the importance of both attributes and highlight the power of branding in this luxurious product category. For example, $3 \mathrm{M}$ is known for its innovation nature, Hallmark is extensively well-known for caring, FedEx is widely famed for its guaranteed speedy delivery service, Disney is drastically associated with fun and family entertainment, and Nike is considerably prominent for individual performance (Davis, 2000). The findings of this study suggest that Callaway is recognised for Excitement, Cleveland is identified for Masculine, Mizuno is acknowledged for Feminine, Nike is well-known for Fashion, Ping is perceived for Reliability, Wholesome, \& Sentiment, Titleist is prominent for Leadership, and Taylor Made is distinguished for Uniqueness. Further, 'the top 5 golf brands occupy over 80\% of global market share' (Wu \& Chang, 2005: 3): Callaway, Taylor Made, Titleist, Ping, \& Cleveland have 25.2\%, 19.2\%, 18.9\%, 9.9\%, and 8.6\%, respectively (Wu and Chang, 2005). Based on the findings of this study, the majority of these top 5 golf brands have better performance than others and none of respondents' demographic characteristics are significant variables for explaining variance in performance. So as such, companies are encouraged to arrange 'competitive priorities' (Phusavat and Kanchana, 2008b: 191) for resource allocation connected with functional and emotional attributes. Particularly, 'the prioritization of critical success factors can help practitioners understand their relative importance and develop improvement plans in cases where they lack sufficient resources to deal with all factors simultaneously' (Chin, Chan, \& Lam, 2008: 437). As advertisements seldom provide any noticeable information related to brand personality, companies may incorporate these findings in their integrated promotional strategies for advertising, 'such as the creation of brand knowledge in consumers' minds from the firm's investment in various marketing and corporate communication programs' (Argyriou, Kitchen, \& Melewar, 2006: 575). The efficiency of this advertising approach deserves more research with precision.

\subsection{Contribution}

This paper demonstrates three notable contributions to research and practices. First, the paper is a pioneer research in the golf equipment market and integrates related studies along with rigorous statistical analyses to shed light on the interrelationships among brand preference, brand personality, customer perceived value, and golfer's performance. Second, this study empirically demonstrates that, in addition to the widely noticeable demographic characteristics (Lin, 2002; Tsai \& Chiu, 2004), brand personality does offer significant supplementary explanation power on golfers' brand preference. 'Traditionally, a marketer segments a market using general variables such as customer demographics and lifestyle. However, several problems have been identified and make the segmentation result unreliable' (Tsai \& Chiu, 2004: 265). So as such, other than conventional 'bases for segmentation' (Bearden, Ingram, \& LaForge, 2001: 156), this paper clearly provides practical guidelines of implementing brand personality for market segmentation and promotion strategies. Third, this work identifies each brand's comparative advantages and disadvantages related to customer perceived value. Findings of this paper shed light on the linkage among brand personality, brand preferences, performance, and customer perceived value, which may help marketers better understand the emerging golf industry in a foreign country. Once companies have a better understanding of their positions in the mind of the customers, they can adjust their branding strategies to position how their brands are perceived by their target customers. The findings and the statistical results provide managers, in different industries, with useful guidelines for implementing appropriate branding management on both functional (i.e., customer perceived value and performance) and emotional attributes (i.e., brand personality) in order to enhance competitiveness.

\subsection{Limitations \& Suggestions for Future Research}

One noticeable limitation of this study lies in the small number of female respondents, but this outcome correctly reflects that golfing in Taiwan is a male-dominant sport. Collecting a larger number of questionnaires (say, 500+) with proportionally more female respondents would enable the analysis of this potential female-golfer niche market. Moreover, another limitation exists in the use of 'self-reported data' (Riemenschneider, Jones, \& Leonard, 2009: 16); that is, the assessment of 'performance was self-reported and therefore may be liable to over-inflation by the respondents' (Meunier-FitzHugh \& Lane, 2009: 303).

Future study shall compare the convincing power of brand personality with other marketing mix elements in order to better understand the relative power of these variables in consumers' purchase decision-making processes. On the other hand, researchers can utilise the same methodology in various geographical regions, such as the United States, Europe, and Japan, in order to explore similarities and differences among those findings in this study. Further, future research may explore the causal relationships among customer perceived value, repurchase behavior, and brand loyalty (Terblanche \& Boshoff, 2010) in order to simultaneously identify their relative influences among customer perceived value variables on repurchase behavior and brand loyalty for arranging competitive priorities (Chin, Chan, and Lam, 2008; Phusavat \& Kanchana, 2008a). Moreover, future study may investigate other possible factors, such as years of golf practices, monthly frequency of playing 18 holes in the previous year, and the amount of practice per month, on performance. 


\section{REFERENCES}

1. Aaker, J.L. (1997). Dimensions of brand personality, Journal of Marketing Research, 34(August), 347-356.

2. Aaker, J.L. (1999). The malleable self, The role of self-expression in persuasion, Journal of Marketing Research, 36(1), 45-57.

3. Aaker, J.L., Fournier, S., and Brasel, S.A. (2004). When good brands do bad, Journal of Consumer Research, 31 (1), 1-16.

4. Anderson, J.C. Jain, C., \& Chintagunta, P. X. (1993). Customer value assessment in business markets, Journal of Business-to-Business Marketing, 1(1), 3-29.

5. Argyriou, E., Kitchen, P.J., \& Melewar, T.C. (2006). The relationship between corporate websites and brand equity- a conceptual framework and research agenda, International Journal of Market Research, 48(5), 575-599.

6. Batra, R., Lehmann, D.R., \& Singh, D. (1993). The brand personality component of brand goodwill, some antecedents and consequences, Paper Presented in Brand Equity and Advertising, Hillsdale, NJ, Lawrence Erlbaum Associates.

7. Bearden, W.O., Ingram, T.N., \& LaForge, R.W. (2001). Marketing Principles and Perspectives. NY, McGraw-Hill/Irwin.

8. Beijing Full Honor Warrant Information Consulting Co. Ltd., (2008). China Golf Irons Manufacturing Research Report in 2007. http,//www.allmyinfo.com/report/pdf/2007-gaoerfu.pdf, retrieved on Oct. 30, 2008.

9. Belk, R.W. (1988). Possessions and the extended self, Journal of Consumer Research,

10. 2(September), 139-168.

11. Bergstrom, A. (2000). Cyberbranding, leveraging your brand on the Internet, Strategy \&

12. Leadership, 28(4), 10-15.

13. Biel, A. (1993). Converting Image into Equity, Papers Presented in Brand Equity and advertising. Hillsdale, NJ, Lawrence Erlbaum Associates.

14. Boshoff, C. \& Gray, B. (2004). The relationships between service quality, customer satisfaction and buying intentions in the private hospital industry, South African Journal of Business Management, 35 (4), 27-37.

15. Boshoff, C., Schlechter, C., \& Ward, S.J. (2011). Consumers' perceived risks associated with purchasing on a branded web site, The mediating effect of brand knowledge, South African Journal of Business Management, 42(1), 45-54.

16. Chin, K-S, Chan, B.L. \& Lam, P-K. (2008). Identifying and prioritizing critical success factors for coopetition strategy, Industrial Management \& Data Systems, 108, 437-454.

17. Chiu, K. K. S., Lin, R. J., Hsu, M. K., \& Huang, L. H. (2010a). Power of branding on Internet service providers, Journal of Computer Information Systems, Spring(Apr.), 112-120.

18. Chiu, K. K-S., Chen, Y-C., Hsu, M. K., \& Chen, K. (2010b). Brand Personality, Brand

19. Preferences, and Customer Perceived Value, Journal of International Academia-Industry Cooperation and Management, 1(3), 31-43.

20. Churchill, G. A., Jr. (1995). Marketing Research, Methodological Foundations. Orlando, FL, The Dryden Press.

21. Davis, S.M. (2000). Brand Asset Management. Jossey-Bass Inc.

22. Devaraj, S., Fan, M., \& Kohli, R. (2006). Examination of online channel preference, Using the structure-conduct-outcome framework, Decision Support Systems, 42, 1089-1103.

23. Dinlersoz, E.M., \& Pereira, P. (2007). On the diffusion of electronic commerce, International Journal of Industrial Organization, 25, 541-574.

24. Dodds, W.B. (1991). In search of value, how price and store name information influence buyers' product perceptions, Journal of Services Marketing, 5(summer), 27-36.

25. Dodds, W.B., Monroe, K.B. \& Grewal, D. (1991). Effects of price, brand, and store information on buyers' product evaluation, Journal of Marketing Research, 28(3), 307-319.

26. Eggert, A., \& Ulaga, W. (2002). Customer perceived value, A substitute for satisfaction in business markets, Journal of Business and Industrial Marketing, 17(2/3), 107-118.

27. Ellis, C. D. (2004). Perspective, Tommy Armour on investing, Financial Analysts Journal, 60(5), $15-16$.

28. Ericksen, M.K. (1996). Using self-congruity and ideal congruity to predict purchase intention, an European perspective, Journal of Euro-Marketing, 6(1), 41-56.

29. Fennis, B.M., \& Pruyn, A.T.H. (2007). You are what you wear, Brand personality influences on consumer impression formation, Journal of Business Research, 60, 634-639.

30. Fornell, C., \& Larcker, D.F. (1981). Evaluating structural equation models with unobservable variables and measurement error, Journal of Marketing Research, 18(1), 39-47.

31. Graeff, T.R. (1996). Using promotional messages to manage the effects of brand and self-image on 
brand evaluations, Journal of Consumer Marketing, 13(3), 4-18.

32. Grewal, D., Monroe, K.B., \& Krishnan, R. (1998). The effects of price-comparison advertising on buyers' perceptions of acquisition value, transaction value and behavioral intentions, Journal of Marketing, 62(April), 46-59.

33. Hansen, H., Samuelsen, B.M., \& Silseth, P.R. (2008). Customer perceived value in B-to-B service relationships, Investigating the importance of corporate reputation, Industrial Marketing Management, 37, 206-217.

34. Helgeson, J.G., \& Supphellen, M. (2004). A conceptual and measurement comparison of self-congruity and brand personality, The impact of socially desirable responding, International Journal of Market Research, 46, 205-233.

35. Hellier, P. K., Geursen, G. M., Carr, R. A., \& Rickard, J. A. (2003). Customer repurchase intention, a general structural equation model, European Journal of Marketing, 37(11/12), 1762-1800.

36. Hemmasi, M., \& Graf, L. A. (1993). Determinants of Faculty Voting Behavior in Union Representation Elections, A Multivariate Model, Journal of Management, 19, 13-32.

37. Ho, C-T. (2009). The relationship between knowledge management enablers and Performance, Industrial Management \& Data Systems, 109(1), 98-117.

38. Hsu, L. L., Chou, C. T., \& Hsu, T. H. (2008). Factors that impact on the perceived benefits of internet international marketing in Taiwanese SMEs, Journal of Targeting, Measurement and Analysis for Marketing, 16(4), 249-260.

39. Jamal, A., \& Goode, M. (2001). Consumers and brands, a study of the impact of self-image congruence on brand preference and satisfaction, Marketing Intelligence and Planning, 19(7), 482-492.

40. Johnson, D. E. (1998). Applied Multivariate Methods for Data Analysts. Pacific Grove, CA, Brooks/Cole Publishing Company.

41. Karlsen, J., \& Nilsson, J. (2007). Club shaft weight in putting accuracy and perception of swing parameters in golf putting, Perceptual and Motor Skill, 105(1), 29-38.

42. Keller, K.L. (1993). Conceptualizing, measuring, and managing customer-based brand equity, Journal of Marketing, 57(January), 1-22.

43. Kerlinger, F.N. (1986). Foundations of Behavioral Research. 2nd Ed. New York, CBS College Publishing.

44. Klaus, P., \& Maklan, S. (2007). The role of brands in a service-dominated world, Journal of Brand Management, 15, 115-122.

45. Kleine, R.E., Kleine, S.S. \& Kernan, J.B. (1993). Mundane consumption and the self, a social-identity perspective, Journal of Consumer Psychology, 2(3), 209-235.

46. Kortge, G.D., \& Okonkwo, P.A. (1993). Perceived value approach to pricing, Industrial Marketing Management, 22, 133-140.

47. Lin, C. (2002). Segmenting customer brand preference, demographic or psychographic, Journal of Product and Brand Management, 11(4), 249-268.

48. Malhotra, N.K. (1988). A scale to measure self-concepts, person concepts and product Concepts, Journal of Marketing Research, 23(November), 456-464.

49. Mehta, A. (1999). Using self-concept to assess advertising effectiveness, Journal of Advertising Research, 39(January/ February), 81-89.

50. Meunier-FitzHugh, K. L. \& Lane, N. (2009). Collaboration between sales and marketing, market orientation and business performance in business-to-business organizations, Journal of Strategic Marketing, 17(3-4), 291-306.

51. Monroe, K.B. (1990). Pricing, Making Profitable Decisions. 2nd ed., McGraw-Hill, New York.

52. Murphy, M.S. (2006). Special report, Equipment-PGA professionals offer continuing Discussion, $P G A$ Magazine, March, 30-44.

53. Na, K.J., Holland, R., Shackleton, J., Hwang, Y-Y., \& Melewar, T.C. (2008). The effect of evaluation criteria on design attributes and brand equity in the product evaluation process, Journal of Brand Management, 16, 195-212.

54. Naidoo, R. \& Leonard, A.C. (2007). Perceived Usefulness, Service Quality and Loyalty

55. Incentives, Effects on Electronic Service Continuance, South African Journal of Business Management, 38 (3)/Sep, 39-48.

56. Nunnally, J. (1978). Psychometric Theory. $2^{\text {nd }}$ ed. New York, McGraw-Hill.

57. Olorunniwo, F., \& Hsu, M. K. (2006). A typology analysis of service quality, customer satisfaction and customer behavioral intentions in mass services, Managing Service Quality, 16(2), 106-123.

58. Ong, C., \& Lai, J. (2006). Gender differences in perceptions and relationships among dominants of e-learning, Computers in Human Behavior, 22, 816-829.

59. Parasuraman, A. \& Grewal, D. (2000). The impact of technology on the quality-value-loyalty chain, a research agenda, Journal of the Academy of Marketing Science, 28(1), 168-174.

60. Petrick, J.F. (2002). Development of a multi-dimensional scale for measuring the perceived value of a 
service, Journal of Leisure Research, 34(2), 119-134.

61. Phusavat, K., \& Kanchana, R. (2008a). Competitive priorities for service providers, perspectives from Thailand, Industrial Management \& Data Systems, 108, 5-21.

62. Phusavat, K., \& Kanchana, R. (2008b). Future competitiveness, viewpoints from manufacturers and service providers, Industrial Management \& Data Systems, 108, 191-207.

63. Phusavat, K., Anussornnitisarn, P., Helo, P., \& Dwight, R. (2009). Performance measurement, roles and challenges, Industrial Management \& Data Systems, 109(5), 646-664.

64. Plummer, J.T. (1985). Brand personality, a strategic concept for multinational advertising, Paper Presented at Marketing Educators' Conference. New York, Young and Rubicam, 1-31.

65. Priilaid, D. \& Rensburg, P.V. (2010). Symbolic and functional brand effects in the hedonic

66. assessment of South African wines, South African Journal of Business Management, 41(3), 47-69.

67. Raggio, R.D., \& Leone, R.P. (2009). Chasing brand value, Fully leveraging brand equity to maximize brand value, Journal of Brand Management, 16, 248-263.

68. Riemenschneider, C. K., Jones, K., \& Leonard, L.N.K. (2009). Web Trust- A Moderator of

69. the Web's Perceived Individual Impact, Journal of Computer Information Systems, Summer, 10-18.

70. Schiffman, L.G. \& Kanuk, L.L. (2000). Consumer Behaviour. 7th ed., Prentice-Hall, Englewood Cliffs.

71. Singh, J., Ehrenberg, A., \& Goodhardt, G.. (2008). Measuring customer loyalty to product variants, International Journal of Market Research, 50(4), 513-530.

72. Sirgy, M.J., Grewal, D., Mangleburg, T.F., Park, J., Chon, K., Claiborne, C.B., Johar, J.S. \& Berkman, H. (1997). Assessing the predictive validity of two methods of measuring self-image congruence, Journal of the Academy of Marketing Science, 25(3), 229-241.

73. Song, M., Benedetto, C.A.D., and Parry, M.E. (2009). The impact of formal processes for market information acquisition and utilization on the performance of Chinese new ventures, International Journal of Research in Marketing, 26, 314-323.

74. Sujan, H., Weitz, B.A., \& Kumar, N. (1994). Learning orientation, working smart, and effective selling, Journal of marketing, 58(July), 39-52.

75. Sung, Y. \& Tinkham, S.F. (2005). Brand personality structures in the United States and Korea, Common and culture-specific factors, Journal of Consumer Psychology. 15(4), 334-350.

76. Terblanche, N.S. \& Boshoff, C. (2010). Quality, value, satisfaction and loyalty amongst race

77. groups, a study of customers in the South African fast food industry, South African Journal of Business Management, 41(1), 1-9.

78. Terpstra, V. \& Sarathy, R. (1997). International Marketing. 7th ed., The Dryden Press, Orlando, FL.

79. Tsai, C.-Y. \& Chiu, C.-C. (2004). A purchase-based market segmentation methodology, Expert Systems with Applications, 27, 265-276.

80. Ulaga, W., \& Eggert, A. (2006). Relationship value and relationship quality. Broadening the nomological network of business-to-business relationships, European Journal of Marketing, 40, 311-327.

81. Wu, C. \& Chang, A. (2005). O-TA Precision (8924TT) Diversified Client Base, Taiwan Equity Research, Tue. $\quad$ Dec. $13, \quad 2005 . \quad$ pp. 1-9. (http,//www.primasia.com/PRIMASIA/DOCS/en03/12677rsha008.pdf), retrieved on Apr. 12, 2009.

82. Wysong, S., Munch, J. \& Kleiser, S. (2004). This brand's for you, An exploratory look at how individual variables can influence brand personality perceptions, American Marketing Association Conference Proceedings, 15, 239-246.

83. Zhang, M. (2007). Impact of brand personality on PALI, a comparative research between two different brands, International Management Review, 3(3), 36-47. 